Original Article

\title{
Toxicity and larvicidal activity on Aedes aegypti of citronella essential oil submitted to enzymatic esterification
}

\author{
Toxicidade e atividade larvicida sobre Aedes aegypti de óleo essencial de citronella \\ submetido à esterificação enzimática
}

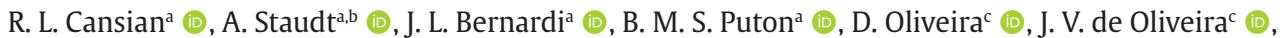

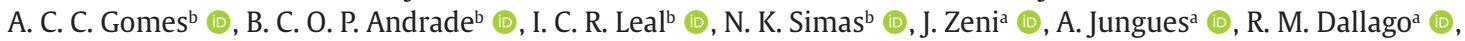 \\ G. T. Backes ${ }^{\mathrm{a}}$ and N. Paroul ${ }^{\mathrm{a}}$ (1) \\ aPrograma de Pós-Graduação em Engenharia de Alimentos, Universidade Regional Integrada do Alto Uruguai e das Missões - URI Erechim, \\ Erechim, RS, Brasil \\ 'Laboratório de Produtos Naturais e Ensaios Biológicos - LaProNEB, Departamento de Alimentos e Produtos Naturais, Faculdade de Farmácia, \\ Centro de Ciências da Saúde - CCS, Universidade Federal do Rio de Janeiro - UFRJ, Rio de Janeiro, RJ, Brasil \\ 'Departamento de Engenharia Química e de Alimentos, Universidade Federal de Santa Catarina - UFSC, Florianópolis, SC, Brasil
}

\begin{abstract}
The essential oil of citronella (Cymbopogon winterianus) has several biological activities, among them the insect repellent action. Some studies showed that cinnamic acid esters can be applied as natural pesticides, insecticides and fungicides. In this context, the objective of the present work was to evaluate the production of esters from citronella essential oil with cinnamic acid via enzymatic esterification. Besides, the essential oil toxicity before and after esterification against Artemia salina and larvicidal action on Aedes aegypti was investigated. Esters were produced using cinnamic acid as the acylating agent and citronella essential oil (3:1) in heptane and $15 \mathrm{wt} \%$ NS 88011 enzyme as biocatalysts, at $70^{\circ} \mathrm{C}$ and $150 \mathrm{rpm}$. Conversion rates of citronellyl and geranyl cinnamates were 58.7 and $69.0 \%$ for NS 88011, respectively. For the toxicity to Artemia salina $\mathrm{LC}_{50}$ results of $5.29 \mu \mathrm{gL} \mathrm{m}^{-1}$ were obtained for the essential oil and $4.36 \mu \mathrm{g} \mathrm{mL}^{-1}$ for the esterified oils obtained with NS 88011. In the insecticidal activity against Aedes aegypti larvae, was obtained $\mathrm{LC}_{50}$ of $111.84 \mu \mathrm{g} \mathrm{mL} \mathrm{m}^{-1}$ for the essential oil of citronella and $86.30 \mu \mathrm{g} \mathrm{mL}^{-1}$ for the esterified oils obtained with the enzyme NS 88011, indicating high toxicity of the esters. The results demonstrated that the evaluated samples present potential of application as bioinsecticide.
\end{abstract}

Keywords: Cymbopogon winterianus, enzymatic esterification, NS 88011, bioinsecticide, Artemia salina, Aedes aegypti.

\begin{abstract}
Resumo
O óleo essencial de citronela (Cymbopogon winterianus) possui diversas atividades biológicas, entre elas a ação repelente a insetos. Alguns estudos mostraram que os ésteres do ácido cinâmico podem ser aplicados como pesticidas naturais, inseticidas e fungicidas. Nesse contexto, o objetivo do presente trabalho foi avaliar a produção de ésteres a partir do óleo essencial de citronela com ácido cinâmico via esterificação enzimática. Além disso, foi investigada a toxicidade do óleo essencial antes e após a esterificação contra Artemia salina e a ação larvicida sobre Aedes aegypti. Os ésteres foram produzidos utilizando ácido cinâmico como agente acilante e óleo essencial de citronela (3: 1) em heptano e $15 \%$ em peso da enzima NS 88011 como biocatalisadores, a $70{ }^{\circ} \mathrm{C}$ e $150 \mathrm{rpm}$. As taxas de conversão de cinamatos de citronelil e geranil foram 58,7 e 69,0\% para NS 88011, respectivamente. Para a toxicidade sobre Artemia salina foram obtidos $\mathrm{CL}_{50}$ de $5,29 \mu \mathrm{g} \mathrm{mL}^{-1}$ para o óleo essencial e $4,36 \mu \mathrm{g} \mathrm{mL}^{-1}$ para os óleos esterificados com NS 88011. Na atividade inseticida contra larvas de Aedes aegypti, obteve-se $\mathrm{CL}_{50}$ de $111,84 \mu \mathrm{mL} \mathrm{mL}^{-1}$ para o óleo essencial de citronela e $86,30 \mu \mathrm{g} \mathrm{mL}^{-1}$ para os óleos esterificados com a enzima NS 88011, indicando alta toxicidade dos ésteres. Os resultados demonstraram que as amostras avaliadas apresentam potencial de aplicação como bioinseticida.
\end{abstract}

Palavras-chave: Cymbopogon winterianus, esterificação enzimática, NS 88011, bioinseticida, Artemia salina, Aedes aegypti.

\section{Introduction}

Citronella, Cymbopogon winterianus Jowitt (Poaceae), is a perennial plant, very resistant to climate change. The essential oil from this plant or their compounds can be

applied in the food, pharmaceutical and cosmetic industries, and is a product widely used as a mosquito repellent and plant defense mechanism (Shasany et al., 2000; Cassel and

*e-mail: cansian@uricer.edu.br

Received: October 16, 2020 - Accepted: March 10, 2021 
Vargas, 2006; El-Helaly et al., 2021; Espadas-Pinacho et al., 2021). Cansian et al. (2017) observed an increase in toxicity on Artemia salina after enzymatic esterification of clove essential oil (Caryophyllus aromaticus L.), proposing that esterification may be a way to potentiate the insecticidal activity of essential oils.

Some studies are available in the literature on cinnamate production and also on the production of esters from the primary alcohols, geraniol and citronellol, present in the citronella essential oil. Paroul et al. (2012) in a study of bioflavors production by enzymatic esterification of citronella essential oil in a solvent free system, comparing two different acids (oleic and propionic acids), observed that the technique used is promising due to the high ester conversions achieved. In the assay using oleic acid the highest yield was obtained under substrates molar ratio on $1: 1,70^{\circ} \mathrm{C}$ and $10 \mathrm{wt} \%$ Novozym 435 enzyme concentration, obtaining a conversion of $98.9 \%$ citronellyl oleate and $82.5 \%$ of geranyl oleate. In the assay using propionic acid the yield was $92.95 \%$ citronellyl propionate and $96.51 \%$ geranyl propionate under the same conditions described for oleic acid.

Zanetti et al. (2017) evaluated the lipase-catalyzed synthesis of geranyl cinnamate and obtained a conversion of 75.85\% under 3:1 molar ratio (geraniol:cinnamic acid), $70{ }^{\circ} \mathrm{C}$ and $15 \mathrm{wt} \%$ of Candida antarctica immobilized lipase (NS 88011). In this study it was observed that geranyl cinnamate presented antimicrobial properties against Staphylococcus aureus and Escherichia coli, but did not present antioxidant activity. Larvicidal activities or geranyl cinnamate toxicity were not evaluated.

There are few studies in the literature evaluating the esterification of citronella essential oil and, to our knowledge, no work about esterification of citronella essential oil with cinnamic acid and evaluation of its toxicity and insecticide properties are available, justifying the accomplishment of the present study that aimed to evaluate the production and the toxicity of the essential oil before and after enzymatic esterification, against $A$. salina and larvicidal action on A. aegypti, aiming to obtain previous data for future application of the same as bioinsecticide.

\section{Material and Methods}

\subsection{Enzyme and substrates}

The commercial lipase used in this work was Candida antarctica (NS 88011) immobilized on a hydrophobic polymeric resin, purchased from Novozymes Brazil (Araucária, PR, Brazil). The chemicals used in the study were all AR grade with no further purification: cinnamic acid (97\% Sigma-Aldrich); $n$-heptane (95\%, Vetec); commercial citronella essential oil (C. winterianus), obtained by hydrodistillation and purchased from Ferquima (São Paulo, Brazil).

\subsection{Chemical characterization of citronella essential oil}

The chemical composition analysis of citronella essential oil was carried out by gas chromatography coupled to mass spectrometry (Shimadzu, Model QP 5050A). A capillary column (PEG) Rtx-Wax (30 m×0.25 mm×0.25 $\mu \mathrm{m}$ ) was used.
Helium was the carrier gas at a flow rate of $1.0 \mathrm{~mL} / \mathrm{min}$; the detector at $1.0 \mathrm{kV}$, split mode (1:50), and the injector at $250{ }^{\circ} \mathrm{C}$ were employed. The initial temperature $40{ }^{\circ} \mathrm{C}$

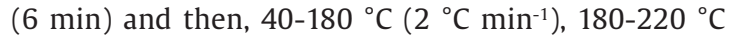
$\left(10^{\circ} \mathrm{C} \mathrm{min}^{-1}\right), 220^{\circ} \mathrm{C}(15 \mathrm{~min})$ was employed. The sample of essential oil was diluted in dichloromethane (Merck, Rio de Janeiro, Brazil) until a final concentration of 5000 ppm. The compounds peaks were integrated in manual mode and compared to the literature and data bank present in the equipment (Wiley, São Paulo, Brazil).

\subsection{Kinetic evaluation of citronellyl and geranyl cinnamates production}

A preliminary kinetic experiment was performed under the experimental conditions reported by Zanetti et al. (2017) to determine the reaction time for synthesis of citronellyl and geranyl cinnamates. The reaction mixture of cinnamic acid, essential oil (EO), (acid/alcohol molar ratio 3:1), enzyme (concentration of $15 \mathrm{wt} \%$, based on the total amount of substrates) and $40 \mathrm{~mL}$ solvent $n$-heptane was kept under mechanical agitation at $150 \mathrm{rpm}$ and $70^{\circ} \mathrm{C}$ during $56 \mathrm{~h}$ of reaction. Aliquots of $100 \mu \mathrm{L}$ were withdrawn from the reaction medium at $0,0.5,1,1.5,2,2.5,3,4,8$, $12,24,28,32,38,48,52$ and $56 \mathrm{~h}$ and analyzed by GC.

\subsection{Reaction conversion and esterification activity}

The analyses of the reaction conversion in terms of citronellyl and geranyl esters were conducted in a gas chromatography (Shimadzu GC-2010) equipped with data processor, using a capillary column (PEG) Rtx-Wax (30 $\mathrm{m} \times 0.25 \mathrm{~mm} \times 0.25 \mu \mathrm{m}$ ), flame ionization detector, with the following temperature program: $40{ }^{\circ} \mathrm{C}(6 \mathrm{~min})$, $40-180{ }^{\circ} \mathrm{C}\left(2{ }^{\circ} \mathrm{C} / \mathrm{min}\right), 180-220{ }^{\circ} \mathrm{C}\left(10{ }^{\circ} \mathrm{C} \mathrm{min}^{-1}\right), 220{ }^{\circ} \mathrm{C}$ (15 min), injector temperature $250^{\circ} \mathrm{C}$, detector at $250{ }^{\circ} \mathrm{C}$, injection in the split, ratio of split $1: 50, \mathrm{H}_{2}(56 \mathrm{kPa})$ as carrier gas, injected volume of $0.4 \mu \mathrm{L}$ of sample diluted in dichloromethane (1:10).

Reaction conversion was calculated based on the reduction of area of limiting reagent on the basis of reaction stoichiometry (Equation 1).

$$
\text { Conversion }(\%)=\frac{\left(S_{b}-S\right)}{S_{b}} .100
$$

Where, $\mathrm{S}_{\mathrm{b}}$ corresponds to the peak area of the limiting reagent before the reaction (geraniol or citronellol) and $\mathrm{S}$ corresponds to the peak area of the limiting reagent after the reaction.

The esterification activity of the enzyme was quantified through the synthesis reaction of oleic acid and ethanol (molar ratio of $1: 3$ by volume) described previously (Rigo et al., 2010). The amount of acid consumed was determined by titration with $\mathrm{NaOH} 0.05 \mathrm{~mol} / \mathrm{L}$. One unit of enzymatic activity (U) was defined as the amount of enzyme necessary to consume $1 \mu \mathrm{mol}$ of fatty acid per minute, under the described assay conditions (Bernardes et al., 2007).

\subsection{Toxicity against Artemia salina}

Toxicity test was carried out using the methodology described by Meyer et al. (1982) and adapted by Cansian et al. (2017). The organisms-test were exposed 
to different concentrations $(0.5,1,5,10,15,20,25$, 50, 75 and $100 \mu \mathrm{g} \mathrm{mL} \mathrm{m}^{-1}$ ) of citronella essential oil and citronella essential oil plus cinnamic acid before and after esterification of 48 hours, using test tubes, each one containing at least 10 nauplii of Artemia salina in artificial saline solution ( $10 \mathrm{~g} \mathrm{~L}^{-1}$ sea salt, $0.7 \mathrm{~g} \mathrm{~L}^{-1}$ sodium bicarbonate and 2.0\% DMSO). The control was carried using $1,10,25,50,75,100,250,500,750$ and $1,000 \mu \mathrm{gL}^{-1}$ of cinnamic acid and $n$-heptane in the same conditions. The $\mathrm{LC}_{50}$ values were determined in triplicate employing non-linear regression model available in GraphPad Prism 6.0 software and expressed as mean \pm standard deviation. The means were compared using the $t$ test, adopting $5 \%$ as significance level.

\subsection{Larvicidal activity against Aedes aegypti}

For the larvicidal activity assay, a methodology adapted from WHO (1970) was used, where previously obtained larvae (Soares-Pinheiro et al., 2017) of Aedes aegypti in the third stage of growth were maintained at rest with the samples (essential oil, essential oil plus cinnamic acid before and after esterification) for 24 hours, and then the counting of living and dead organisms was carried out. The samples (essential oil before and after esterification) and control (cinnamic acid and $n$-heptane) were evaluated, in triplicate, in concentrations between 25 and $500 \mu \mathrm{g} \mathrm{mL}^{-1}$.

\section{Results and Discussion}

\subsection{Chemical characterization of essential oil}

The chemical composition of citronella essential oil (Table 1) presented as major components citronellal (38.98\%), followed by geraniol (20.56\%) and citronellol (17.54\%). The results are qualitatively similar to those obtained by Paroul et al. (2012), with quantitative variations. The values found for the primary alcohols, which can be reacted with cinnamic acid, geraniol and citronellol, correspond to $38.1 \%$ of the total oil composition.

\subsection{Production of citronellyl and geranyl cinnamates}

The preliminary kinetic results of citronellyl and geranyl cinnamates are presented in Figure 1, and indicates that the optimum reaction time at the evaluated experimental conditions was 52 hours.

The results obtained for the peak areas of the components of interest before and after the esterification reaction are described in Table 2. The reduction of the areas of limiting substrates (citronellol and geraniol) showed conversions of $58.7 \%$ for citronellol and $69 \%$ for geraniol, confirmed by the increase of ester areas. These results are similar to those obtained by Paroul et al. (2012) in a study of esterification of citronella essential oil with propionic acid, where it was obtained a conversion of $55.4 \%$ for citronellol and $77.9 \%$ for geraniol into its respective esters, under reaction conditions of $60^{\circ} \mathrm{C}, 1: 1$ molar ratio (oil:acid) and $1 \mathrm{wt} \%$ of Novozym 435.

After enzyme recovery from reaction medium by filtration, its activity was determined. A reduction of
$39 \%$ was observed after 52 hours of reaction (initial activity of $1,559.4 \mathrm{U} \mathrm{g} \mathrm{g}^{-1}$ and final activity of $\left.949.0 \mathrm{U} \mathrm{g}^{-1}\right)$. This reduction is similar to that obtained by Padilha and Augusto-Ruíz (2007) who observed a $44.4 \%$ reduction in porcine pancreatic lipase enzyme solution activity under much milder conditions $\left(60\right.$ min reaction at $38^{\circ} \mathrm{C}$ ), which can possibility the reuse of the biocatalyst or evaluate the fed batch mode of operation.

The reaction mixture, without prior purification, was used for the biological activities' tests.

Table 1. Chemical composition of Cymbopogon winterianus essential oil.

\begin{tabular}{ccc}
\hline RT & Compounds & Area (\%) \\
\hline 11.3 & D-Limonene & 3.46 \\
28.4 & Citronellal & 38.98 \\
33.0 & $\beta$-Elemene & 1.10 \\
34.8 & Linalool & 1.57 \\
39.4 & Geranial & 1.26 \\
40.9 & $\Delta$-Cadiene & 2.58 \\
42.1 & Cedrene & 0.82 \\
43.8 & Citronellylacetate & 2.55 \\
44.4 & $\alpha$-Muurolene & 2.61 \\
45.0 & Citronellol & 17.54 \\
48.9 & Geraniol & 20.56 \\
58.4 & Germacren-4-ol & 0.64 \\
60.1 & Elemol & 2.33 \\
Total & & 96 \\
Unoxygenated monoterpenes & 7.97 \\
Unoxygenated sesquiterpenes & 2.61 \\
Monoterpene alcohols & 39.67 \\
Sesquiterpene alcohols & 2.97 \\
Aldehydes & & 40.24 \\
Esters & 2.55 \\
\hline
\end{tabular}

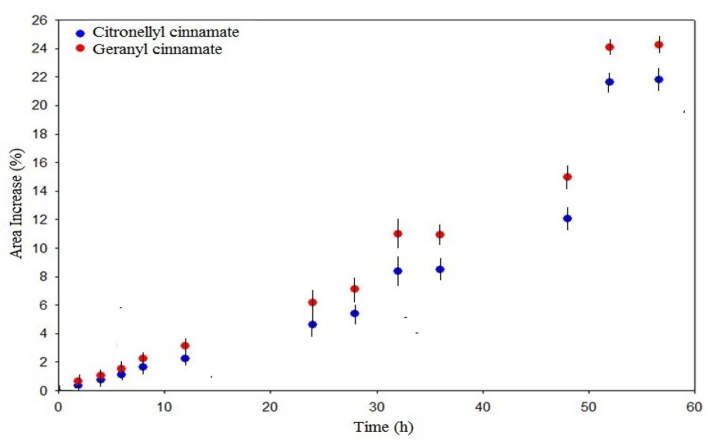

Figure 1. Kinetics of citronellyl and geranyl cinnamates production (molar ratio alcohol/acid 3:1, enzyme $15 \mathrm{wt} \%$, temperature $70^{\circ} \mathrm{C}$, $150 \mathrm{rpm})$. 


\subsection{Toxicity against Artemia salina}

The toxicity results of citronella essential oil and citronellyl and geranyl cinnamates against nauplii of $A$. salina are shown in Figure 2. The mean lethal concentrations $\left(\mathrm{LC}_{50}\right)$ of the essential oil and esterified citronella oil obtained from the correlation equations between sample concentration and A. salina mortality are shown in Table 3.

It can be observed that the esters showed similar toxicity to citronella essential oil (5.29 and $4.36 \mu \mathrm{g} \mathrm{mL}^{-1}$, respectively). The control cinnamic acid and the reaction components before esterification presented low toxicity (439.59 and $329.74 \mu \mathrm{g} \mathrm{mL} \mathrm{m}^{-1}$, respectively) and n-heptane

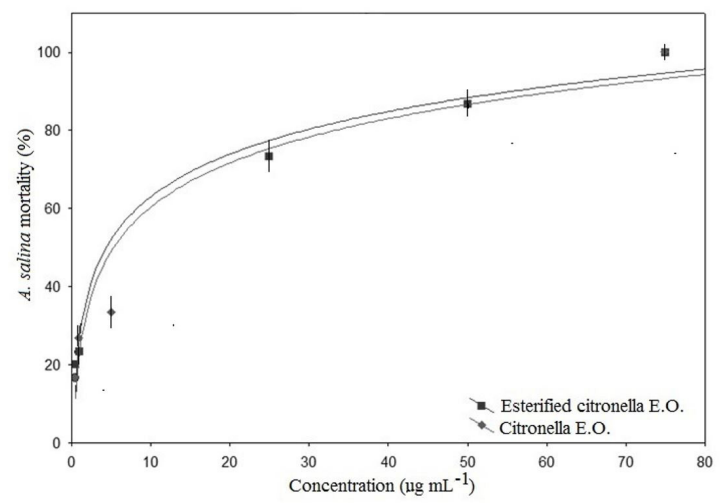

Figure 2. Mortality percentage of Artemia salina nauplii in relation to increased sample concentration. did not cause toxicity at the evaluated concentrations. The $\mathrm{LC}_{50}$ results of the evaluated samples show that they present high toxicity, following the definition of Meyer et al. (1982) who considered that a product is toxic when it has a $\mathrm{LC}_{50}$ value $<1000 \mu \mathrm{g} \mathrm{mL}^{-1}$ and Amarante et al. (2011) who report that a sample is very toxic when its $\mathrm{LC}_{50}$ is less than $100 \mu \mathrm{g} \mathrm{mL} \mathrm{m}^{-1}$.

The same toxicity behavior for essential and esterified oils was obtained by Cansian et al. (2017) which

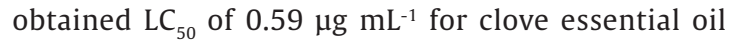
(Caryophyllus aromaticus) and $0.12 \mu \mathrm{g} \mathrm{mL}^{-1}$ for eugenyl acetate produced by the esterification of clove essential oil, although with 10 to 40 times higher toxicity to these last.

\subsection{Larvicidal activity in Aedes aegypti}

The determination of the larvicidal activity was made from the percentage of dead Aedes aegypti larvae as a function of the concentration of the evaluated samples. Results are presented in Table 4.

Similar result for citronella oil on Aedes aegypti mosquito larvae was reported by Silva et al. (2017) who obtained a $\mathrm{LC}_{50}$ value of $120 \mu \mathrm{g} \mathrm{mL}-1$ for the citronella essential oil of the species Cymbopogon winterianus. Cheng et al. (2003) considered good larvicidal agent substances with an $\mathrm{LC}_{50}$ value of less than $100 \mu \mathrm{g} \mathrm{mL} \mathrm{m}^{-1}$. It can be observed that the esterification of the geraniol and citronellol monoterpenes promoted an increase in the larvicidal activity in the test with A. aegypti larvae (111.84 to $86.30 \mu \mathrm{g} \mathrm{mL}^{-1}$ ). However, the control (cinnamic acid) also showed larvicidal activity $\left(98.85 \mu \mathrm{g} \mathrm{mL}^{-1}\right)$ and its presence in the esterified oil contributed to the increased activity in the product.

Table 2. Substrate consumption and esters production with NS 88011 enzyme in closed system reaction for 56 hours.

\begin{tabular}{lcc}
\hline Substrates and Reaction Products & Reaction Mix Peak Area & Peak Area After Reaction \\
\hline Citronellol & $1390985.9(100 \%)$ & $574.513 .9(41.3 \%)$ \\
Geraniol & $1699928.8(100 \%)$ & $527294.8(31.0 \%)$ \\
Citronellyl cinnamate & 0 & $1153384.4(44.2 \%)$ \\
Geranyl cinnamate & 0 & $1453839.2(55.8 \%)$ \\
\hline
\end{tabular}

Table 3. Determination of the $\mathrm{LC}_{50}$ of citronella essential oil before and after esterification with cinnamic acid on A. salina.

\begin{tabular}{lccc}
\hline \multicolumn{1}{c}{ Sample } & \multicolumn{1}{c}{ Correlation } & $\mathbf{R}^{\mathbf{2}}$ & $\mathbf{L} \mathbf{C}_{\mathbf{5 0}}\left(\boldsymbol{\mu} \mathbf{g} \mathbf{~ \mathbf { ~ L }} \mathbf{-}^{-1}\right)$ \\
\hline Commercial citronella E.O. & $\mathrm{y}=37.5962 \cdot \log _{10}(\mathrm{x})+22.8026$ & 0.9906 & $5.29 \pm 0.21$ \\
Reaction before esterification & $\mathrm{y}=40.8329 \cdot \log _{10}(\mathrm{x})-52.8241$ & 0.9318 & $329.74 \pm 16.27$ \\
Esterified citronella E.O. & $\mathrm{y}=36.2112 \cdot \log _{10}(\mathrm{x})+26.8386$ & 0.9485 & $4.36 \pm 0.23$ \\
Cinnamic acid & $\mathrm{y}=18.6240 . \log _{\mathrm{n}}(\mathrm{x})-63.3430$ & 0.9547 & $439.59 \pm 14.62$ \\
\hline
\end{tabular}

Table 4. Determination of the $\mathrm{LC}_{50}$ of citronella essential oil before and after esterification with cinnamic acid on Aedes aegypti larvae.

\begin{tabular}{lccc}
\hline \multicolumn{1}{c}{ Sample } & Correlation & $\mathbf{R}^{2}$ & LC $\mathbf{5 0}\left(\boldsymbol{\mu} \mathbf{~} \mathbf{~ L L}^{-1}\right)$ \\
\hline Commercial citronella E.O. & $\mathrm{y}=87.6265 \cdot \log _{10}(\mathrm{x})-129.5125$ & 0.9308 & $111.84 \pm 3.72$ \\
Reaction before esterification & $\mathrm{y}=58.909 \cdot \log _{10}(\mathrm{x})-68.3524$ & 0.8514 & $102.11 \pm 1.03$ \\
Esterified citronella E.O. & $\mathrm{y}=54.251 \cdot \log _{10}(\mathrm{x})-55.0295$ & 0.8341 & $86.30 \pm 1.15$ \\
Cinnamic acid & $\mathrm{y}=56.3911 \cdot \log _{10}(\mathrm{x})-62.5004$ & 0.8103 & $98.85 \pm 2.36$ \\
\hline
\end{tabular}


The reaction components before esterification showed intermediate larvicidal activity between essential oil and cinnamic acid due to the dilution of the latter, as expected. The n-heptane did not cause toxicity at the evaluated concentrations. As esters are fairly stable in relation to essential oil (Surburg and Panten, 2016), this esterification product has the potential to use as larvicide to control diseases transmitted by $A$. aegypti.

\section{Conclusions}

New data on the production of cinnamic acid esters by enzymatic esterification of geraniol and citronellol from citronella essential oil were presented in this paper, showing a promising methodology for the production of these compounds. Conversion of citronellol and geraniol to corresponding esters reached $58.7 \%$ and $69 \%$, respectively. The esterified oil presented high toxicity to Artemia salina ( $4.36 \mu \mathrm{g} \mathrm{mL}-1$ ), being effective against Aedes aegypti mosquito larvae $\left(86.30 \mu \mathrm{g} \mathrm{mL} \mathrm{m}^{-1}\right)$, showing that these substances can be used as larvicide to prevent the spread of vector of various diseases.

\section{Acknowledgements}

The authors thank the Coordination for the Improvement of Higher Education Personnel - Brazil (CAPES) - Finance Code 001, National Council for Scientific and Technological Development - Brazil (CNPq) and Research Support Foundation of the State of Rio Grande of Sul - Brazil (FAPERGS) for scholarships and financial support.

\section{References}

AMARANTE, C.B., MÜLLER, A.H., PÓVOA, M.M. and DOLABELADO, M.F., 2011. Estudo fitoquímico biomonitorado pelos ensaios de toxicidade frente à Artemia salina e de atividade antiplasmódica do caule de aninga (Montrichardia linifera). Acta Amazonica, vol. 41, no. 3, pp. 431-434. http://dx.doi.org/10.1590/S004459672011000300015.

BERNARDES, O.L., BEVILAQUA, J.V., LEAL, M.C.M.R., FREIRE, D.M.G. and LAGNONE, M.G., 2007. Biodiesel fuel production by the transesterification reaction of soybean oil using immobilized lipase. Applied Biochemistry and Biotechnology, vol. 32, pp. 136140. http://dx.doi.org/10.1007/s12010-007-9043-5.

CANSIAN, R.L., VANIN, A.B., ORLANDO, T., PIAZZA, S.P., PUTON, B.M.S., CARDOSO, R.I., GONÇALVES, I.L., HONAISER, T.C., PAROUL, N. and OLIVEIRA, D., 2017. Toxicity of clove essential oil and its ester eugenyl acetate against Artemia salina. Brazilian Journal of Biology = Revista Brasileira de Biologia, vol. 77, no. 1, pp. 155-161. http://dx.doi.org/10.1590/1519-6984.12215. PMid:27382998.

CASSEL, E. and VARGAS, R.M.F., 2006. Experiments and Modeling of the Cymbopogon winterianus Essential Oil Extraction by Steam Distillation. Journal of the Mexican Chemical Society, vol. 50, no. 3, pp. 126-129.

CHENG, S.S., CHANG, H.T., TSAI, H.K. and CHEN, W.J., 2003. Bioactivity of selected plant essential oils against the yellow fever mosquito Aedes aegypti larvae. Bioresource Technology, vol. 89, no. 1, pp. 99-102. http://dx.doi.org/10.1016/S0960-8524(03)00008-7. PMid:12676507.
EL-HELALY, A.A., EL-MASARAWY, M.S. and EL-BENDARY, H.M., 2021. Using Citronella to Protect Bees (honeybee Apis mellifera L.) from certain Insecticides and Their Nano Formulations. Brazilian Journal of Biology = Revista Brasileira de Biologia, vol. 81, no. 4, pp. 899-908. http://dx.doi.org/10.1590/1519-6984.230140. PMid:33053125.

ESPADAS-PINACHO, K., LÓPEZ-GUILLÉN, G., GÓMEZ-RUIZA, J. and CRUZ-LÓPEZ, L., 2021. Induced volatiles in the interaction between soybean (Glycine max) and the Mexican soybean weevil (Rhyssomatus nigerrimus). Brazilian Journal of Biology $=$. Revista Brasileira de Biologia, vol. 81, no. 3, pp. 611-620. http:// dx.doi.org/10.1590/1519-6984.227271.

MEYER, B.N., FERRIGNI, N.R., PUTNAM, J.E., JACOBSEN, L.B., NICHOLS, D.E. and MCLAUGHLIN, J.L., 1982. Brine Shrimp: A Convenient General Bioassay for Active Plant Constituents. Journal of Medicinal Plants Research, vol. 45, no. 5, pp. 31-34. http://dx.doi.org/10.1055/s-2007-971236. PMid:17396775.

PADILHA, M.E.S. and AUGUSTO-RUIZ, W., 2007. Hidrólise enzimática do óleo de pescado. Food Science and Technology (Campinas), vol. 27, no. 2, pp. 285-290. http://dx.doi.org/10.1590/S010120612007000200013.

PAROUL, N., GRZEGOZESKI, L.P., CHIARADIA, V., TREICHEL, H., CANSIAN, R.L., OLIVEIRA, J.V. and DE OLIVEIRA, D., 2012. Solvent-free production of bioflavors by enzymatic esterification of Citronella (Cymbopogon winterianus) essential oil. Applied Biochemistry and Biotechnology, vol. 166, no. 1, pp. 13-21. http:// dx.doi.org/10.1007/s12010-011-9399-4. PMid:21976151.

RIGO, E., NINOW, J.L., DI LUCCIO, M., OLIVEIRA, J.V., POLLONI, A.E., REMONATTO, D., ARBTER, F., VARDANEGA, R., DE OLIVEIRA, D. and TREICHEL, H., 2010. Lipase production by solid fermentation of soybean meal with different supplements. LebensmittelWissenschaft + Technologie, vol. 43, no. 7, pp. 1132-1137. http:// dx.doi.org/10.1016/j.lwt.2010.03.002.

SHASANY, A.K., LAL, R.K., PATRA, N.K., DAROKAR, M.P., GARG, A., KUMAR, S. and KHANUJA, S.P.S., 2000. Phenotypic and RAPD diversity among Cymbopogon winterianus Jowitt accessions in relation to Cymbopogon nardus Rendle. Genetic Resources and Crop Evolution, vol. 47, no. 5, pp. 553-559. http://dx.doi. org/10.1023/A:1008712604390.

SILVA, T.I., ALVES, A.C.L., SANTOS, T.M., ALVES, W.S., SILVA, J.S. and AZEVEDO, F.R., 2017. Efeito larvicida de óleo essencial de Cymbopogon winterianus Jowitt sobre larvas de Aedes aegypti L. (Diptera: Culicidae). Revista Cultivando o. Saber (Cumaná), vol. 10, no. 1, pp. 128-136.

SOARES-PINHEIRO, V.C., DASSO-PINHEIRO, W., TRINDADE-BEZERRA, J.M. and TADEI, W.P., 2017. Eggs viability of Aedes aegypti Linnaeus (Diptera, Culicidae) under different environmental and storage conditions in Manaus, Amazonas, Brazil. Brazilian Journal of Biology = Revista Brasileira de Biologia, vol. 77, no. 2, pp. 396-401. http://dx.doi.org/10.1590/1519-6984.19815. PMid:27533732.

WORLD HEALTH ORGANIZATION - WHO, 1970. Insecticide resistance and vector control. Geneva: World Health Organization, pp. 443 , Technical Report Series.

SURBURG, H. and PANTEN, J. 2016. Common fragrance and flavor materials: Preparation, properties and uses. 6th ed. Wiley, 392p. http://dx.doi.org/10.1002/9783527693153.

ZANETTI, M., CARNIEL, T.K., VALÉRIO, A., OLIVEIRA, J.V., OLIVEIRA, D., ARAÚJO, P.H.H., RIELLA, H.G. and FIORI, M.A., 2017. Synthesis of geranyl cinnamate by lipase catalyzed reaction and its evaluation as an antimicrobial agent. Journal of Chemical Technology and Biotechnology, vol. 92, no. 1, pp. 115-121. http:// dx.doi.org/10.1002/jctb.4998. 